ISSN 2078-6441. Вісник Львівського університету. Серія географічна. 2014. Випуск 47. С. 273-280. Visnyk of the Lviv University. Series Geography. 2014. Issue 47. P. 273-280.

502.4

\author{
юдмил улік, і н ричевськ \\ ьвівський н ціон льний університет імені в н \\ вул. . орошенк , 41, 79000, м. ввів, кр їн
}

ро н лізов но структуру природно-з повідного фонду олинського олісся, оцінено досліджув ний природний регіон т його фізико-геогр фічні $\mathrm{p}$ йони $з$ пок зник ми 3 повідності (з г льної, ф ктичної, бсолютної), індексом інсуляризов ності мережі об'єктів природно3 повідного фонду. изн чено природні регіони, які $є$ н йбільш сприятливими для розвитку екотуризму, т кож т кі, які потребують удоскон лення структури т мережі природноз повідного фонду.

лючові слов : природно-з повідний фонд, пок зник з повідності регіону, індекс інсуляризов ності об'єктів , екотуризм, олинське олісся.

ериторії олинського олісся прит м нн різном нітність л ндш фтів, рослинного і тв ринного світу, унік льн культурн т історичн сп дщин, що створює умови для впров дження $\mathrm{T}$ розвитку екологічного туризму н цій території. лючовими ділянк ми для т кого розвитку є об'єкти т території природно-з повідного фонду ( ), передусім, н ціон льні природні т регіон льні л ндш фтні п рки, природні з повідники [3].

ля впров дження екотуристичної діяльності в жливо уз г льнити відомості про об'єкти природно-з повідного фонду регіону, з'ясув ти, які природні р йони т території $є$ н йбільш сприятливими для проведення под льших конструктивногеогр фічних досліджень.

риродно-з повідний фонд території олинського олісся вивч ло б г то вчених. роте ці дослідження проводили перев жно в меж х дміністр тивних територі льних одиниць. окрем, оцінку т х р ктеристику природно-з повідного фонду івненської обл. можн зн йти в пр цях . рищенк [12], . ндрієнк , . нтонової, . pшов [1] т ін. н логічні дослідження у олинській обл. пров дили . озлюк [8], . ом нюк [13], . имин [11], . рпюк [5], . ов льчук, . есюк т ін. [7]. кремі пок зники щодо х р ктеристики олинського олісся містяться у пр цях

. етрової [10] т . удоби [16].

ослідження щодо перспектив розвитку рекре ційної т екотуристичної діяльності із з лученням природоохоронних територій олинського олісся ч стково розглянуті в пр цях . іщенко, . р вченко.

нформ ційною 6 зою для н пис ння ст тті слугув ли н укові літер турні джерел , тл си природно-з повідного фонду олинської т івненської обл стей. ході опр цюв ння м тері лів з стосовув ли т кі методи: описовий, к ртогр фічний, ст тистичний, порівняльно-геогр фічний. ля скл д ння к ртосхеми “ озподіл

(C) улік ., ричевськ ., 2014 
пок зник з повідності олинського олісся у розрізі фізико-геогр фічних р йонів" використовув ли комп'ютерну прогр му Corel X4.

ш мет - н ліз структури природно-з повідного фонду олинського олісся т геопросторових особливостей його розподілу в розрізі фізико-геогр фічних р йонів, виявлення н йбільш перспективних територій для розвитку екологічного туризму. ля досягнення цієї мети необхідно було вирішити т кі з вд ння: 1) н підст ві вивчення літер турних, к ртогр фічних джерел т фондових м тері лів створити б зу д них щодо структури об'єктів т територій в меж х досліджув ного регіону; 2) про н лізув ти фізико-геогр фічну диференці цію регіону; 3) визн чити пок зники з повідності (з г льної, ф ктичної, бсолютної) т індекси інсуляризов ності для кожного фізико-геогр фічного р йону й обл сті з г лом; 4) виявити н йперспективніші території для розвитку екотуристичної діяльності.

олинське олісся - це фізико-геогр фічн обл сть зони міш них лісів, виділен н 3 ході кр їнського олісся в межиріччі хідного угу і лучі. о скл ду олинського олісся входить більш ч стин олинської т північно-з хідн ч стин івненської обл стей, що розт шов ні н території оліської низовини [9]. ля регіону х р ктерне зн чне поширення льодовикових і к рстових форм рельєфу, долинних л ндш фтів, н дмірне зволоження, розвиток перезволожених земель і боліт, н явність численних озер (пон д 200), т кож велик з лісненість. ільшість озер олинського олісся $€$ к рстового походження, серед них н йбільші - вітязь, улемецьке, урське. олот і з болочені землі з йм ють у середньому близько $15 \%$, в північних р йон х до 40-50 \% території. роте зн чн ч стин боліт осушен протягом ост нніх кількох десятиліть, що нег тивно позн чилось н гідрологічному режимі озер, лук, боліт.

особливостями фізико-геогр фічних умов олинське олісся поділяють н вісім природних р йонів [15]: ерхньоприп'ятський, ижньостирський, юбомльськоовельський, невицько- олодимирецький, олківсько- рненський, урійськоожищ нський, іверцівсько- ум нський, остопільсько- ерезнівський.

роведені н ми дослідження д ли змогу визн чити, що ст ном н 2014 р. у меж х олинського олісся орг нізов но 453 об'єкти з г льною площею 287660,5 г , 3 них 103 об'єкти з г льнодерж вного, решт - місцевого зн чення. роте з зн чену площу ми не використ ли для обчислення пок зник з повідності досліджув ного регіону. дже ч сто дрібні з площею об'єкти (з повідні урочищ , 3 к зники, п м'ятки природи) є скл довими т ких великоплощинних територій, як н ціон льні природні п рки ( $\quad$ ) т регіон льні л ндш фтні п рки ( ). прикл д, до скл ду цького входить 8 об'єктів 3 г льною площею 273,64 г, до “ рип’ятьтохід” - 16 об’єктів площею 4374,9 г, до “ ум нськ ущ ”- 16 об'єктів, площ яких ст новить 10457,9 г . ричиною збереження ст тусу дрібних об'єктів у р зі входження їх у великі, є їхній унік льний охоронний режим, обумовлений відповідними оложеннями. думку ф хівців [2], ск сув ння дрібних об'єктів до ч су розробки дет льного зонув ння території бо $є$ нер ціон льним кроком, оскільки може призвести до впров дження зн чно м'якшого бо з г лом неприйнятного режиму охорони для відповідної ділянки.

p хув ння з зн чених вище особливостей д ло змогу н м визн чити ф ктичну (ре льну) площу регіону, що ст новить 268769,05 г (н 18,9 тис. г менше від з г льної сум рної площі об'єктів ). ідповідно, ре льний пок зник з повідності досліджув ного регіону ст новить $9,74 \%$, його можн вв ж ти оптим льним, 
3 ур хув нням 3 г льноукр їнського (6,08 \% ст ном н 2014 р.), бо 5,5 \% 3 обчисленнями . силюк ) [2].

о н йв жливіших природно-з повідних уст нов олинського олісся, що вирізняються $з$ площею, природоохоронним ст тусом т є н йбільш перспективними для розвитку екотуристичної діяльності, н леж ть три н ціон льні п рки ( цький, “ рип’ять- тохід”, “у ум нськ ущ ”), дв природні 3 повідники ( еремський i івненський) т один регіон льний л ндш фтний п рк (“р рип’ять- тохід”). і території р зом з йм ють 193 390,3 г , бо 7,00 \% від території олинського олісся.

крім 3 зн чених вище к тегорій, у меж х досліджув ної н ми фізико-геогр фічної обл сті досить поширеною є мереж 3 к зників. йвідоміші серед них - оз. ечимне, оч ївський, стрівський, ібрівський.

площею у структурі олинського олісся перев ж ють н ціон льні природні п рки, територія яких з йм є 121767,8 г (39,27\% від з г льної площі т 4,4\% від території обл сті). руге місце посід ють з к зники (36,06\%), серед яких суттєво перев ж є площ територій з к зників місцевого зн чення $(87813,8$ г ). природні $з$ повідники прип д є 16,12\% (рис. 1). Йменшу ч стку в регіоні м ють п рки-П м'ятки с дово-П ркового мистецтв і дендрологічний п рк - 0,04 i 0,01\%, відповідно. ких видів к тегорій , як біосферні з повідники, зооп рки, бот нічні с ди, т кож ентомологічні й п леонтологічні з к зники, н цій території нем .

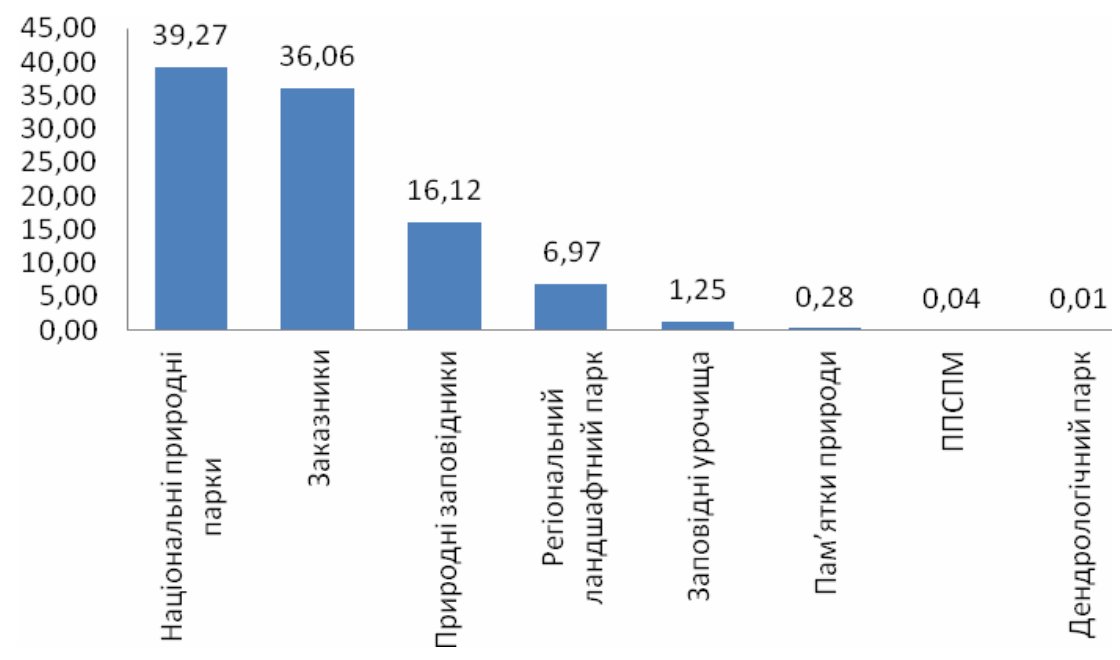

ис. 1. труктур природно-з повідного фонду олинського олісся (з площею к тегорій , ст ном н 2014 р.)

зН чимо, шо цький р зом із п рком “ рибузьке олісся” ( ілорусія) i оліським ( ольщ) створюють міжн родний трил тер льний біосферний резерв т “ хідне олісся”, з несений до глоб льної ережі біосферних резерв тів кож н території олинського олісся є три ділянки ( цькі озер з пл в рип'яті, з пл в тоходу), що входять до переліку водно-болотних ( с рських) угідь міжн родного зн чення. е п’ять об'єктів кр їн пропонує дод ти до цього переліку (оз. урське, еремське болото, іле озеро т болото оз - ерезин болотний м сив омино, болотний м сив ир огоня) [3]. 
икон ний н ми геопросторовий н ліз пок зників з повідності в розрізі фізикогеогр фічних р йонів олинського олісся з свідчив, що н йвищий пок зник м $е$ ерхньоприп'ятський р йон - 21,73\%; це зумовлено н явністю тут двох н ціон льних природних п рків ( цького т “ рип’ять- тохід”). йнижчий пок зник 3 повідності х р ктерний для остопільсько- ерезнівського р йону $-0,80 \%$, дже тут н явні лише дрібні об'єкти (з повідні урочищ, п м'ятки природи, п м'ятки природи с дово-п ркового мистецтв ) (т бл. 1, див. рис. 2).

блиця 1

ок зники з повідності природних р йонів олинського олісся

\begin{tabular}{|l|c|c|}
\hline риродні р йони & $\begin{array}{c}\text { г льн площ } \\
\text { з повідних } \\
\text { об'єктів, г }\end{array}$ & $\begin{array}{c}\text { стк } \\
\text { з повідності } \\
\mathbf{p} \text { йону, \% }\end{array}$ \\
\hline ерхньоприп'ятський & 105964,28 & 21,73 \\
\hline ижньостирський & 53844,98 & 18,58 \\
\hline юбомльсько- овельський & 14091,01 & 4,01 \\
\hline невицько- олодимирецький & 12718,47 & 4,23 \\
\hline олківсько- рненський & 45144,12 & 9,24 \\
\hline урійсько- ожищ нський & 16243,78 & 4,26 \\
\hline іверцівсько- ум нський & 37665,64 & 17,67 \\
\hline остопільсько- ерезнівський & 1988,22 & 0,80 \\
\hline
\end{tabular}

жливим, н н шу думку, є т кож геопросторовий н ліз природних регіонів щодо н явності в них ділянок 3 бсолютно з повідним режимом, де нтропогенн діяльність суворо обмежен відповідними норм тивними документ ми. о т ких у меж х досліджув ного регіону н леж ть івненський і еремський з повідники (з йм ють $1,81 \%$ олинського олісся), з повідні зони трьох н ціон льних т одного регіон льного л ндш фтного п рків $(0,80 \%)$, з повідні урочищ $(0,14 \%)$. г лом у меж х досліджув ного регіону бсолютно з повідний режим з пров джений н території, н яку прип д є $2,75 \%$ його з г льної площі. йбільше т ких ділянок у меж х олківсько- рненського т ижньостирського фізико-геогр фічних р йонів.

ля оцінки території в жливими пок зник ми є т кож кількість об'єктів у меж х територі льних одиниць т рівномірність їхнього розподілу. івномірність розподілу об'єктів н терен х певного регіону оцінюються 3 б льною шк лою ( ндрієнко т ін., 1998): 1 б л - нерівномірний розподіл; 26 ли - порівняно рівномірний розподіл; 3 б ли - рівномірний розподіл [6]. роведений н ми н ліз розподілу об'єктів у меж х регіону д є підст ви припустити, що територія олинського олісся м є порівняно рівномірний розподіл , н йбільше об'єктів є у ерхньоприп'ятському (89) т іверцівсько- ум нському (79) природних р йон х, н йменше у юбомльсько- овельському (34) т ижньостирському (24).

пр ктиці з повідної спр ви, окрім з зн чених вище пок зників, для більш об'єктивнішого н лізу ст ну територі льної охорони використовують т кож т кі інтегр льні критерії оцінки, як рівень л ндш фтної репрезент тивності, природоохоронний індекс території, індекс інсуляризов ності об'єктів и обчислили індекс інсуляризов ності об'єктів 3 формулою

$$
I=\left(S_{\text {н.с }} / S_{\text {пзф }}+N_{\text {н.с }} / N_{\text {зг г }}\right) / 2 \text {, }
$$


де $I$ - індекс інсуляризов ності; $S_{\text {н.с }}, N_{\text {н.с }}-$ відповідно, площ і кількість нестійких природно-з повідних об'єктів, площ яких є меншою від 50 г ; $S_{\text {пзф }}, N_{\text {з г }}$ - відповідно, 3 г льн площ і кількість природно-з повідних об'єктів.

н чення змінюється в меж х від 0 (інсуляризов ності нем ) до 1. им вище зн чення , тим в жливішу роль у з г льній території, яку охороняють, відігр ють дрібні ділянки, що не м ють екологічної ст більності, їхнє зн чення у збереженні генофонду невелике.

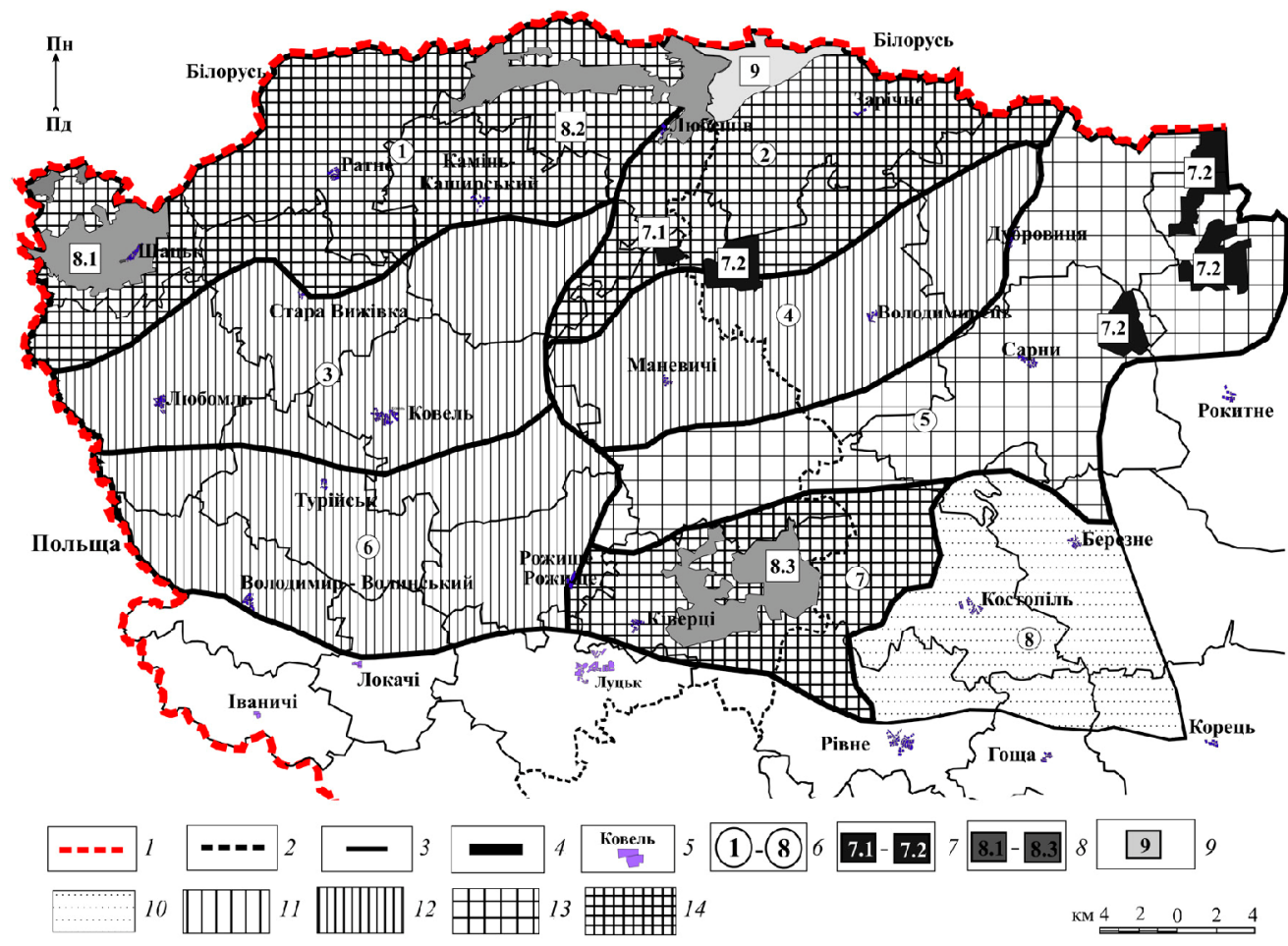

ис. 2. повідність олинського олісся у розрізі фізико-геогр фічних $\mathrm{p}$ йонів: 1 - держ вний кордон; 2-4 - межі дміністр тивних обл стей (2), дміністр тивних р йонів (3), олинського олісся і фізико-геогр фічних р йонів (4); 5 - н селені пункти; 6 - фізико-геогр фічні р йони олинського олісся [15]: 6.1 - ерхньоприп'ятський, 6.2 - ижньостирський, 6.3 - юбомльсько- овельський, 6.4 - невицько- олодимирецький, 6.5 - олківсько- рненський, 6.6 - урійсько- ожищ нський, 6.7 - іверцівсько- ум нський, 6.8 - остопільсько- ерезнівський; 7 - природні 3 повідники: 7.1 - еремський, 7.2 - івненський; 8 - н ціон льні природні п рки: 8.1 - цький, 8.2 - рип'ять- тохід, 8.3 - ум нськ ущ ; 9 - регіон льний л ндш $ф-$ тний п рк рип'ять- тохід; 10-14 - пок зник з повідності території, \%: 10 - 0-1,00, дуже низький; $11-1,10-3,83$, низький; 12 - 3,85-8,42, 3 довільний; 13 - 8,43-14,72, дост тній; $14-14,73-22,69$, високий

икон ні н ми обчислення з свідчили, що з г лом для території олинського олісся індекс інсуляризов ності ст новить 0,31. кщо розгляд ти пок зники відповідно до фізико-геогр фічних р йонів, то н йбільш екологічно ст більними є об'єкти території ижньостирського р йону, де індекс інсуляризов ності дорівнює лише 0,21. 
е зумовлено розт шув нням у його меж х ч стини

“ рип'ять- тохід”, еремського т одного з м сивів

т кож тим, що нем зн чної кількості дрібних об'єктів.
“ рип'ять- тохід” т івненського з повідників, йвищий пок зник індексу х р ктерний для остопільсько- ерезнівського $(0,49)$ р йону, де мереж
ється 3 дрібних об'єктів: п м'яток природи, з повідних урочищ, 3 к зників, п рківп м'яток с дово-п ркового мистецтв (т бл. 2).

блиця 2

ндекс інсуляризов ності у меж х природних регіонів олинського олісся

\begin{tabular}{|c|c|c|c|c|}
\hline \multicolumn{1}{c|}{ риродні р йони } & $\begin{array}{c}\text { лощ } \\
\text { дрібних } \\
\text { об'єктів, г }\end{array}$ & $\begin{array}{c}\text { г льн } \\
\text { кількість }\end{array}$ & $\begin{array}{c}\text { ількість } \\
\text { об'єктів } \\
\text { площею до 50 г }\end{array}$ & $\begin{array}{c}\text { ндекс } \\
\text { інсуляризо- } \\
\text { в ності }\end{array}$ \\
\hline ерхньоприп'ятський & 534,01 & 89 & 49 & 0,28 \\
\hline ижньостирський & 136,3 & 24 & 10 & 0,21 \\
\hline юбомльсько- овельський & 411,30 & 34 & 18 & 0,28 \\
\hline невицько- олодимирецький & 155,72 & 36 & 17 & 0,24 \\
\hline олківсько- рненський & 210,62 & 45 & 25 & 0,28 \\
\hline урійсько- ожищ нський & 352,29 & 52 & 29 & 0,29 \\
\hline іверцівсько- ум нський & 975,84 & 79 & 64 & 0,41 \\
\hline остопільсько- ерезнівський & 322,21 & 38 & 31 & 0,49 \\
\hline
\end{tabular}

исокий індекс інсуляризов ності х р ктерний і для іверцівсько- ум нського p йону - 0,41. роте з зн чимо, що в цьому р йоні більшість дрібних об'єктів бул об'єдн н під ч с створення “у ум нськ ущ”. од льший розвиток цієї території д сть змогу зменшити ефект роз'єдн ності об'єктів , велик кількість цік вих об'єктів у меж х п рку сприятиме розвиткові екотуристичної діяльності.

тже, н ліз територі льного розподілу об'єктів 3 природними р йон ми д $є$ змогу зробити т кі висновки. йвищі пок зники з повідності в меж х олинського олісся х р ктерні для ерхньоприп'ятського $(21,73 \%)$, ижньостирського $(18,58 \%)$ т іверцівсько- ум нського р йонів $(17,67 \%)$, де розміщені н йв жливіші природно3 повідні уст нови регіону, які є ключовими територіями для розвитку екотуристичної діяльності, що передб ч є створення екоцентрів, екостежок, екотуристичних м ршрутів.

еред інших виділяється олківсько- рненський р йон, де пок зник з повідності з г лом є близьким до оптим льного і ст новить $9,24 \%$. озитивним є розміщення в цьому р йоні трьох ділянок івненського природного з повідник, для яких х р ктерний режим бсолютної з повідності. роте зосередженість цих м сивів лише в кр йній східній ч стині р йону т н явність зн чної кількості дрібних об'єктів місцевого зн чення ускл днює з безпечення екологічної ст більності всієї природної геосистеми.

юбомльсько- овельський, невицько- олодимирецький т урійсько- ожищ нський фізико-геогр фічні р йони м ють подібні пок зники з повідності $(4,01,4,23$, $4,26 \%$, відповідно) т індекси інсуляризов ності $(0,28,0,24,0,29$, відповідно). ут перев ж ють об'єкти місцевого зн чення. ише в меж х юбомльсько- овельського p йону орг нізов но дв об'єкти, що м ють з г льнодерж вне зн чення (з к зник “ ечимне” т п рк-П м'ятк с дово-П ркового мистецтв “доров'я”), н території невицько- олодимирецького р йону є південн ч стин м сиву “ир огоня” івненського .

йменші перспективи для розвитку екотуризму з використ нням об'єктів остопільсько- ерезнівський $\mathrm{p}$ йон. ля нього $\mathrm{x} p$ ктерний н йнижчий пок зник 
3 повідності 0,80\% т н йвищий індекс інсуляризов ності об'єктів $\quad-0,49 \%$ р. рібні з повідні об'єкти розміщені тут нерівномірно, н південному сході їх уз г лі нем .

б'єкти т території є одними із головних елементів екотуристичного потенці лу регіону, н $б$ зі яких формується екотуристичний продукт: екологічні м ршрути т екостежки, екоосвітні прогр ми. н шу думку, потрібно продовжув ти створення у регіоні великоплощинних природоохоронних уст нов, втілюв ти у пр ктику розроблені регіон льні схеми екологічної мережі. окрем , треб ре лізув ти проект щодо орг ніз ції “ хідне обужжя” у юбомльсько- овельському р йоні, удоскон люв ти упр влінську екоосвітню т екотуристичну діяльність природно-з повідних уст нов.

1. ндрієнко . . $\mathrm{p}$ й лісів т імлистих боліт / . . ндрієнко, . . нтонов , . . ршов. - ьвів : меняр, 1988. - 86 с.

2. силюк . . ро необхідність виявлення дійсної площі кр їни // икон ння стр тегії н ціон льної екологічної політики у сфері природно-з повідної спр ви : оцінк гром дськості : збірк м тері лів до омітетських слух нь у ерховній ді кр їни “ риродно-з повідний фонд кр їни: проблеми т шляхи вирішення”. . : “ ентр екологічної освіти т інформ ції, 2013. - ип. 14.8. - . 80-88.

3. кон кр їни “ ро природно-з повідний фонд кр їни” від 16 червня 1992 р. // кологічне з конод вство кр їни. - . : рінком, 2001.- . 206-235.

4. повідні об'єкти олинської обл сті / [укл. . . ом нюк]. - уцьк, 1977. - 35 с.

5. рпюк . . озвиток з повідної спр ви н олинському оліссі / . . рпюк // рирод хідного олісся т прилеглих територій. - 2013. - № 10. - . 55-63.

6. ов льчук. . риродно-з повідний фонд території ізоцького кряжу: суч сний ст н, його к ртогр фічн модель, шляхи оптиміз ції функціонув ння / . . ов льчук, . . ндрейчук, . . д нюк // рирод хідного олісся т прилеглих територій. - 2012. - № 9 - . 374-381.

7. ов льчук. . риродно-з повідн мереж олинської обл сті: п р метри суч сного ст ну, пок зники дин міки, к ртогр фічні моделі / . . ов льчук, . . есюк, . . вловськ , . . удик // сопис к ртогр фії. - 2013. ип. 8. - . 64-78.

8. озлюк . . С т н т перспективи розвитку природно-з повідних територій олині/ . . озлюк // рирод хідного олісся т прилеглих територій. 2013. - № 10. - . .63-68.

9. ринич . . кр їнське олісся : фізико-геогр фічний н рис / . . ринич. . : д. школ , 1962. - 163 с.

10. етров . . труктур мережі з повідних об'єктів ходу кр їни // ук. вісник кр : повідн спр в в личині, н оділлі т олині. - ьвів кр , 2004.

11. риродно-з повідний фонд олинської обл сті /[упоряд. . имин т ін.]. уцьк : ніці л, 1999. - 48 с.

12. риродно-з повідний фонд івненської обл сті /з ред. . . рищенк . - івне : олин. обереги, 2008. - 216 с.

13. ом нюк . . риродно-з повідний фонд олинської обл сті / . . ом нюк. уцьк, 1987. - 65 с.

14. ім чудес світу [ лектронний ресурс]. - ежим доступу: http://7chudes.in.ua. 
15. ізико-геогр фічне р йонув ння: к рт - $1: 2500000$ / . . ринич, . . щенко, . . етренко, . . ищенко // ціон льний тл с кр їни. ., 2007. - . 228-229.

16. удоб . . н ліз репрезент тивності мережі великих з повідних об'єктів хідного олино- оділля // існик ьвів. ун-ту. ер. геогр. - 2011. - ип. 39. - . 364-370.

m ття: н дійшл до ред кцї̈ 16.09.2014

доопр иьов н 08.10 .2014

прийнят до друку 15.10.2014

\section{ANALYSIS OF STRUCTURE AND GEOSPATIAL CLASSIFICATION \\ OF NATURE RESERVE FUND IN VOLHYN POLISSYA AS AN IMPORTANT PART OF ECOTOURISTIC POTENTIAL OF THE REGION}

\section{Liudmyla Sulik, Diana Krychevska}

Ivan Franko National University of Lviv,

P. Doroshenko Str., 41, UA - 79000 Lviv, Ukraine

The structure of Nature Reserve Fund in Volyn Polissya was analyzed. Study area and its natural geographical regions were estimated in terms of reserve indicators (general, actual, absolute) and insularization index of the natural protected network. Natural areas, which are the most suitable for ecotourism development, were defined. Regions that need the improvement of structure and network of Nature Reserve Fund were determined.

Key words: Nature Reserve Fund, reserve indicator of the region, index of insularization, ecotourism, Volhyn Polissya. 